\title{
The Kuroshio edge exchange processes (KEEP) study - an introduction to hypotheses and highlights
}

\section{George T.F. Wong ${ }^{\mathrm{a}, \mathrm{b}, *}$, Shenn-Yu Chao ${ }^{\mathrm{c}}$, Yuan-Hui Li ${ }^{\mathrm{b}, 1}$, Fuh-Kwo Shiah ${ }^{\text {b, } 2}$}

\author{
${ }^{\mathrm{a}}$ Department of Ocean, Earth and Atmospheric Sciences, Old Dominion University, Norfolk, \\ VA 23529-0276, USA \\ ${ }^{\mathrm{b}}$ The National Center for Ocean Research, National Science Council, P.O. Box 23-13, Taipei, \\ 10617, Taiwan, ROC \\ ${ }^{\mathrm{c}}$ Horn Point Laboratory, University of Maryland Center for Environmental Science, Cambridge, \\ MD 21613-0775, USA
}

\begin{abstract}
The Kuroshio edge exchange processes (KEEP) study is a multidisciplinary study on the internal cycling of material, especially carbon, within the East China Sea Shelf and the exchange of material between this Shelf and its adjoining Kuroshio. The project has been ongoing since 1989. The East China Sea Shelf is a net sink of atmospheric carbon dioxide. Rich supplies of nutrients, mostly from the upwelling of the Kuroshio Subsurface Water and, to a lesser extent, from the riverine discharges, notably from the Changjiang, sustain a high primary production (550 $\mathrm{mg} \mathrm{C} \mathrm{m}^{-2} \mathrm{~d}^{-1}$ ) on the Shelf and help the draw down of carbon dioxide. The sum of the demands for organic carbon for sustaining the observed bacterial production in the water column and the rate of sulfate reduction in the sediments of this Shelf appears to exceed its primary production. This suggests that a large fraction of the photosynthetically fixed carbon is recycled effectively within the Shelf. However, a comprehensive and definitive carbon budget for the Shelf cannot yet be constructed. Organic particles that survive oxidation within the Shelf and reach the Okinawa Trough are deposited in a belt along the upper northwestern slope of the Trough. A particle-rich mid-depth layer and the very high fluxes of sinking particles off the
\end{abstract}

\footnotetext{
* Corresponding author. Tel.: 001-757-583-4285; fax: 001-757-683-5303.

E-mail address: gwong@odu.edu (G.T.F. Wong)

${ }^{1}$ On leave from: Department of Oceanography, University of Hawaii, 1000 Pope Rd., MSB 307, Honolulu, HI 96822, USA.

${ }^{2}$ Present address: Institute of Oceanography, National Taiwan University, P.O. Box 23-13, Taipei, Taiwan, ROC.
} 
shelf break northeast of Taiwan suggest active cross shelf transport of particles from the Shelf to the Okinawa Trough. The cyclonic eddy at the shelf edge northeast of Taiwan is an important pathway for the exchange of dissolved and particulate materials between the Shelf and the Kuroshio. Nitrogen fixation may be a significant contributor of combined nitrogen to the oligotrophic Kuroshio Surface Water and the Taiwan Strait Warm Water so that it may support up to $25 \%$ of the new production in the Kuroshio Surface Water. (C) 2000 Elsevier Science Ltd. All rights reserved.

Keywords: East China Sea; Upwelling; Nutrient; Kuroshio

\section{Introduction}

The Bohai, the Yellow Sea (Huanghai) and the East China Sea (Tunghai) constitute a series of interconnected marginal seas that extend from 41 to $25^{\circ} \mathrm{N}$ along the coast of China (Fig. 1). It is one of the larger system of marginal seas in the world. It is bounded to the west by the Asian continent and it serves as the receiving water of much of the river runoff of the densely populated northern China. The East China Sea is the southernmost and, by far, the largest and deepest member of these three seas. It receives more than $90 \%$ of the river runoff to this marginal sea system (Table 1) and it is the only member that can communicate directly with the North Pacific either through the Kuroshio or through the Tsushima Warm Current via the Japan Sea. Thus, the East China Sea is an important conduit that may channel the large quantities of terrigenous and anthropogenic material from northern Asia (Zhang, 1995; Wong et al., 1998) to the North Pacific.

The East China Sea includes the water on the East China Sea Shelf, or the Tunghai Shelf, and the water in the deep Okinawa Trough. Most of the East China Sea Shelf has depths between 50 and $100 \mathrm{~m}$. The shelf break occurs at about $170 \mathrm{~m}$. The Okinawa Tough is an almost enclosed basin with a maximum depth exceeding $2000 \mathrm{~m}$. The East China Sea extends from the Cheju Island, at about $33^{\circ} 20^{\prime} \mathrm{N}$, to the north to the northern coast of the island of Taiwan to the south. It exchanges freely with the Yellow Sea through its open northwestern portion of its northern boundary west of Cheju Island. It is connected to the Japan Sea at the northeastern portion of its northern boundary through the Tsushima Strait. The Tsushima Warm Current flows from the East China Sea through this Strait into the southern Japan Sea and it eventually reaches the northwestern Pacific through the Tsugaru Strait. The volume transport of the Tsushima Warm Current at the Tsushima Strait has been estimated to be 1-3 Sv (Harada and Tsunogai, 1986; Nozaki, 1989; Chern et al., 1990). At its southern boundary, the East China Sea is connected to the South China Sea through the Taiwan Strait where the warm, saline and nutrient-poor Taiwan Strait Warm Water may enter the East China Sea. This Taiwan Strait Warm Water is believed to be Kuroshio water from the east of Luzon or a mixture of Kuroshio water and South China Sea water (Fan and Yu, 1981; Fan, 1982; Wang and Chern, 1988, 1992; Shaw, 1989). The volume transport of Taiwan Strait Warm Water into the East China Sea is 


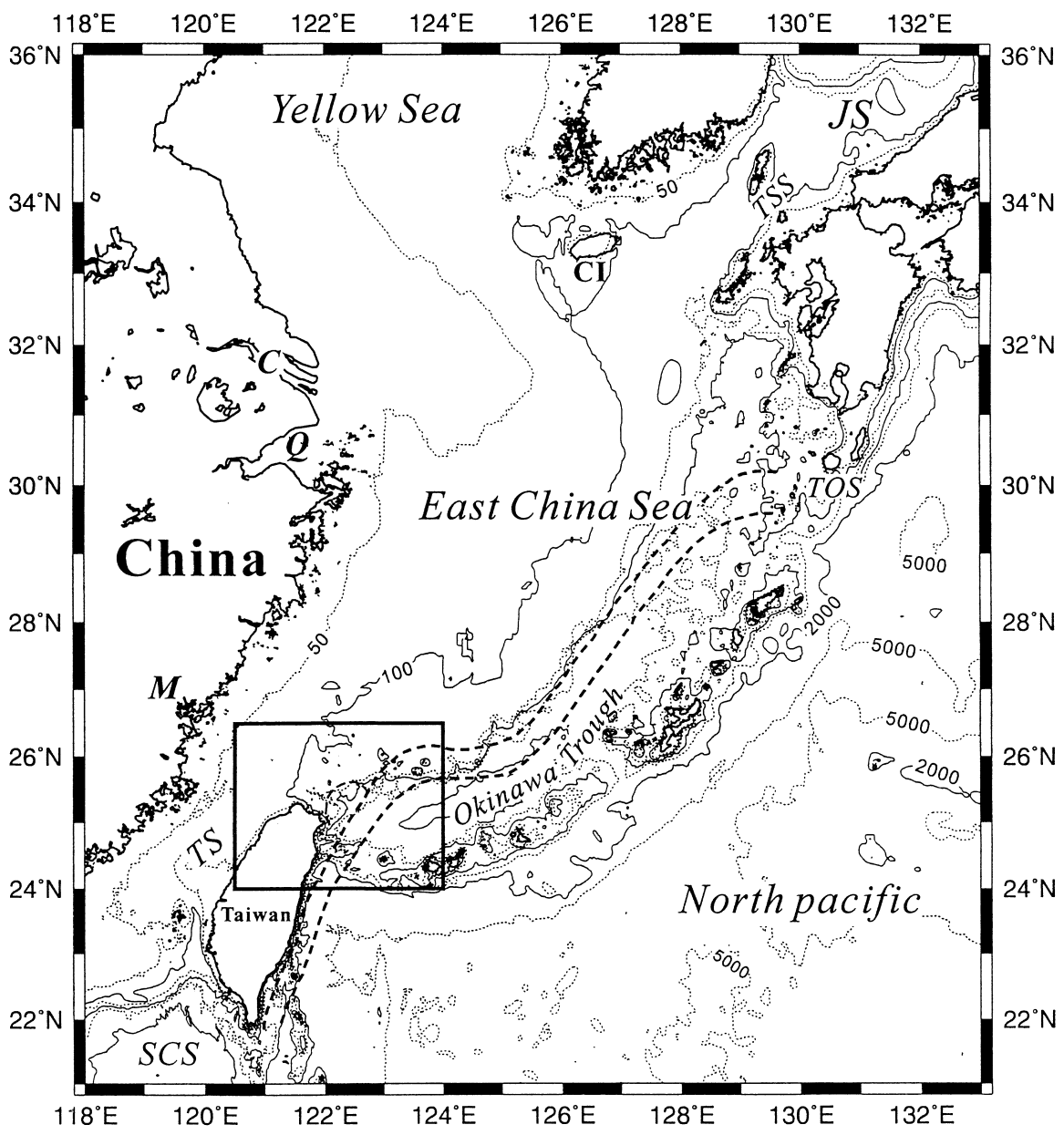

Fig. 1. The study area. The dashed line with and without arrows indicate the general trajectory of the core and the western edge of the Kuroshio respectively. The area in the rectangle is enlarged in Fig. 2. C - Changjiang; CI - Cheju Island; JS - Japan Sea; M - Minjiang; Q - Qiantangjiang; SCS — South China Sea; TOS — Tokara Strait; TS — Taiwan Strait; TSS — Tsushima Strait.

poorly known. Estimations around 1 Sv have been suggested (Wyrtki, 1961; Jan et al., 1994). However, its input to the East China Sea may be episodic and greatly influenced by the wind field. The volume transport is believed to be much smaller in the Winter (Wang and Chern, 1988). To the east, the East China Sea is bounded by the Okinawa Island chain. At the southeastern corner of the Sea, the Kuroshio enters the East China Sea from the Philippine Sea through the Suao-Yonaguni Pass between Taiwan and the Yonaguni Island. Immediately upon its entry into the East China Sea, the northward-flowing Kuroshio impinges onto a portion of the East China Sea Shelf that runs in an east-west direction. As a result, the current turns east and then skirts along the northwestern flank of the upper slope of the Okinawa Trough until it 
Table 1

Some characteristics of the Bohai-Yellow Sea-East China Sea system ${ }^{\mathrm{a}}$

\begin{tabular}{|c|c|c|c|c|}
\hline & Bohai & Yellow Sea & East China Sea & \\
\hline Area $\left(10^{6} \mathrm{~km}^{2}\right)$ & 0.09 & 0.39 & 0.74 & (Sverdrup et al., 1942; \\
\hline$<200 \mathrm{~m}$ & 0.09 & 0.39 & 0.51 & Zhang et al., 1990; \\
\hline Average depth (m) & 20 & 40 & 300 & Wang, 1991; Nozaki \\
\hline Volume $\left(10^{6} \mathrm{~km}^{3}\right)$ & 0.0015 & 0.017 & 0.22 & $\begin{array}{l}\text { et al., 1991; Zhang and } \\
\text { Liu, 1994) }\end{array}$ \\
\hline \multirow[t]{4}{*}{ River inflow } & Daliaohe (9.4) & & Changjiang (928) & \multirow{4}{*}{$\begin{array}{l}\text { (Zhang et al., 1994; } \\
\text { Zhang, 1995) }\end{array}$} \\
\hline & Luanhe (4.2) & & Qiantangjiang (35.3) & \\
\hline & Haihe (9.6) & & & \\
\hline & Huanghe (41.0) & & Minjiang (58.4) & \\
\hline
\end{tabular}

a - Annual river discharge given in brackets in $\mathrm{km}^{3} \mathrm{yr}^{-1}$.

re-enters the North Pacific Ocean south of Japan through the Tokara Strait. As the Kuroshio travels along the northwestern slope of the Okinawa Trough, it exchanges extensively with the East China Sea Shelf Water, especially through the actions of eddies along the shelf break (Chen et al., 1992; Tang et al., 1999). As a result, the warm, saline and nutrient poor Kuroshio Surface Water is imported into the shelf while the fresher and colder East China Sea Shelf Water is exported to the Kuroshio through frontal processes. Furthermore, the cold and nutrient-rich Kuroshio Subsurface Water is brought to the shelf by topographically induced upwelling. This upwelling water can be observed as a pool of cold surface water at the shelf break northeast of Taiwan(Yin, 1973; Chu, 1976; Fan, 1980; Liu, 1983; Liu and Pai, 1987; Liu et al., 1989; Wong et al., 1989; Su et al., 1990).

The primary purpose of the Kuroshio edge exchange processes (KEEP) study was to investigate the processes for material exchange between the East China Sea Shelf and the adjoining Kuroshio. Since KEEP is part of the Joint Global Ocean Flux Study (JGOFS), special attention has been given to the internal cycling of carbon within the East China Sea Shelf and the exchange of carbon between the East China Sea Shelf and its adjoining geochemical reservoirs. The working hypotheses of the project were as follows: (1) the East China Sea Shelf is a net sink of atmospheric carbon dioxide; (2) the East China Sea Shelf is a net source of organic carbon to the waters further offshore; and (3) topographically induced upwelling at the shelf break is a major source of nutrients that support primary production in the East China Sea Shelf.

\section{Physics of the water column}

The exchanges between the Kuroshio Surface and Subsurface Waters with the East China Sea Shelf Water are temporally variable (Chern and Wang, 1990a,b, 1992a,b; 


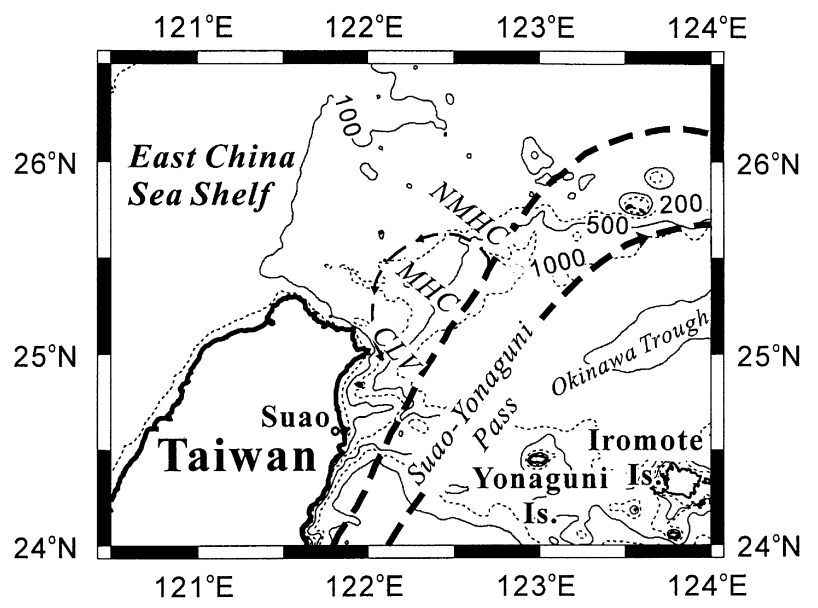

Fig. 2. An enlargement of the area in the rectangle in Fig. 1. CLV - Chi-Lung Valley; MHC - Mien-Hua Canyon; NMHC - North Mien-Hua Canyon. Thin dashed curve northeast of Taiwan represents the cyclonic eddy centered around MHC. The upwelling Kuroshio Subsurface Water occupies the center of the eddy. The core and the western edge of the Kuroshio are shown as in Fig. 1.

Wong et al., 1991) since they are affected by wind forcing and buoyancy forcing and both forcings are temporally variable (Chern et al., 1990; Chuang and Wu, 1992; Hsueh et al., 1992; Liu et al., 1992a). As a result, a variety of surface expressions of these exchanges has been observed (Lin et al., 1992a,b). Nevertheless, the upwelling of the Kuroshio Subsurface Water onto the shelf at the shelf break northeast of Taiwan is a permanent feature that occurs year-round (Liu et al., 1992a,b). At times, the upwelling intensity is high enough so that the upwelling water may reach the sea-surface and become evident as a pool of cold and nutrient-rich surface water. The average upwelling rate is about $5 \mathrm{~m} \mathrm{~d}^{-1}$. Over the upwelling zone with an area of about $2900 \mathrm{~km}^{2}$, the upwelling volume transport is $0.2 \mathrm{~Sv}$ and $2 \times 10^{9} \mathrm{~g} \mathrm{~N} \mathrm{~d}^{-1}$ are brought to the top $60 \mathrm{~m}$ of the upwelling area.

When the northward-flowing Kuroshio collides with the east-west running shelf of the southern East China Sea Shelf, it bifurcates (Fig. 2). The main stem turns east while a branch, the Kuroshio Branching Current, intrudes onto the shelf over the North Mien-Hua Canyon. Part of the Kuroshio Branching Current curls back to form a cyclonic eddy centered around the Mien-Hua Canyon with a diameter of about 70 km (Tang and Yang, 1993; Tang et al., 1999). The upwelling Kuroshio Subsurface Water forms the center of the eddy. The sea-ward flowing limb of the eddy rejoins the Kuroshio off the northeastern tip of Taiwan possibly over the Chi-Lung Valley. The discovery of this cyclonic recirculation eddy northeast of Taiwan has advanced our understanding about the circulation in the East China Sea significantly, for the eddy provides a major pathway for the seaward dispersal of waterborne materials. The southward-flowing arm of this eddy was first observed by point measurements of currents (Chuang et al., 1993; Hsueh et al., 1993). Lacking mesoscale coverage at the time, it was initially conjectured that the southward flow might be a countercurrent on 
the inshore side of the Kuroshio, more or less continuously along the shelf break of the East China Sea. Years of speculation ended on recent ADCP (acoustic doppler current profiler) measurements of subtidal circulation patterns. The paper describing subtidal circulation northeast of Taiwan by Tang et al. $(1999,2000)$ is a culmination of decade-long observation efforts. Statistical analysis of sea surface temperature by Tseng et al. (2000) facilitates the discussion of water masses and upwelling of the East China Sea in subsequent papers. East China Sea is one of a few seas where internal waves of the elevation type are as common as that of depression type. Hsu et al. (2000) analyzed Synthetic Aperture Radar (SAR) images to derive characteristics of internal waves in the East China Sea and to demonstrate the generation of both depression and elevation internal waves by upwelling under different mixed layer conditions.

\section{Volume transport, nutrient and carbon budgets}

The major water masses in the East China Sea Shelf are the nutrient-rich and less saline Changjiang Diluted Water along the Chinese coasts, the warm and nutrient poor Kuroshio Surface Water along the shelf edge, the cold and nutrient-rich upwelling Kuroshio Subsurface Water at the shelf edge and the warm and nutrient poor Taiwan Strait Warm Water intruding from the Taiwan Strait (Chen et al., 1995; Wong et al., 1998). (The water along the Chinese coasts has been called Changjiang Diluted Water and China Coastal Water. The former name indicates the dominance of Changjiang as a source of fresh water to the coastal region (Table 1). The latter name suggests that there are other rivers that discharge into the coastal region. In areas farther removed from the Changiang, the influence of the other rivers, such as the Minjiang at the southeastern corner of the East China Sea Shelf, may also be significant.) First-order budgets for the volume transports of water, salt and the nutrients have been estimated for the East China Sea Shelf (Li, 1994; Chen, 1996, 1998; Liu, 1998, 1999; Chen et al., 1999). About 0.5 Sv of each of Kuroshio Surface Water and the upwelling Kuroshio Subsurface Water are imported into the East China Sea Shelf while $1.1 \mathrm{~Sv}$ of the East China Sea Shelf Water is exported to the Kuroshio and the Japan Sea. The upwelling at the upwelling center northeast of Taiwan represents at least one third of the total upwelling onto the East China Sea Shelf along the shelf break. Upwelling brings about $3 \times 10^{11}, 1 \times 10^{10}$ and $4 \times 10^{11} \mathrm{~mol} \mathrm{yr}^{-1}$ of nitrate, phosphate and silicate to the shelf. The nutrient budget is dominated by the input of nutrient via upwelling since this input is more than five times of that from the rivers. The allochthonous nutrients can support a new production of $70-80 \mathrm{mg}-\mathrm{C} \mathrm{m}^{-2} \mathrm{~d}^{-1}$. About $40 \mathrm{mg}-\mathrm{C} \mathrm{m}^{-2} \mathrm{~d}^{-1}$ is buried in the shelf while $30 \mathrm{mg}-\mathrm{C} \mathrm{m}^{-2} \mathrm{~d}^{-1}$ is exported offshore. It should be noted that the input from the Taiwan Strait Warm Water has been left out in all these modelling exercises. While this water is nutrient poor and will not be a significant source of nutrients to the East China Sea Shelf, its volume transport may affect the water balance and the salt balance. Additional work is needed to verify these values for water, nutrient and carbon transports. By combining the mass balance approach and direct current measurements in two seasons, Liu et al. (2000) further examined the intra-annual variations of the transport of nutrients onto 
the shelf by upwelling and the role of the Taiwan Strait Warm Water on the nutrient budget of the East China Sea Shelf. They reported that upwelling provides a rather constant flux of nutrients to the Shelf. The influence of the Taiwan Strait Warm Water may be significant and it is temporally rather variable. Furthermore, the entrainment of the upwelling Kuroshio Subsurface Water may be a significant source of nutrient to the surface layer of the Kuroshio. Wang et al. (2000) examined the air-sea exchange of $\mathrm{CO}_{2}$ in the East China Sea and estimated that the East China Sea Shelf is a net sink of atmospheric $\mathrm{CO}_{2}$, absorbing as much as 0.013 to $0.030 \mathrm{Gt} \mathrm{C} \mathrm{yr}^{-1}$. Hung et al. (2000) studied the role of the dissolved (DOC) and particulate (POC) organic carbon in the carbon cycle of the East China Sea Shelf and found that both DOC and POC are exported from the Shelf to the Kuroshio.

\section{Nutrient dynamics and biological production}

Large spatial and temporal variations in biomass and primary production can be found in the East China Sea. The inventory of chlorophyll $a$ in the euphotic zone varies by more than an order of magnitude. These spatial variations correspond approximately with the distribution of the water masses. Higher inventories $\left(>50 \mathrm{mg} \mathrm{m}^{-2}\right.$ ) are found in the Changjiang Diluted Water. The highest inventory is found at the frontal zone off the mouth of Changjiang. Further offshore, the inventory decreases seaward to $<10 \mathrm{mg} \mathrm{m}^{-2}$ in the Kuroshio Surface Water (Gong et al., 1996). Superimposed on this general trend of decreasing inventory of chl $a$ with distance from the shore is a patch of moderately elevated inventories (up to about $50 \mathrm{mg} \mathrm{m}^{-2}$ ) at the upwelling center at the shelf break (Chen, 1995a; Gong et al., 1997). Preliminary measurements of primary production suggest that its distribution may follow approximately the same trend as that of biomass (Chen, 1995b; Shiah et al., 1995, 1996; Gong et al., 1997; Chen et al., 1998). However, the observed primary productions are significantly, up to $70 \%$ in some areas, higher than those reported previously (Guo, 1991). The mean value reaches $550 \mathrm{mg} \mathrm{C} \mathrm{m}^{-2} \mathrm{~d}^{-1}$ over the East China Sea Shelf. The fraction of primary production that is supported by nitrate averages about 0.4 in the Shelf. The lowest value, 0.15 , was found in the Changjiang Diluted Water while the highest, 0.82, was found in the upwelling zone (Chen et al., 1998). The dominant phytoplankton species in the upwelling region and the shelf region are Thalassionema nitzschioides and Skeletonema costatum, respectively. A high abundance of the nitrogen fixer, Trichodesmium spp., is found in the Kuroshio.

Runoff from the Changiiang and the upwelling of Kuroshio Subsurface Water are two major sources of nutrients that fuel the primary production in the East China Sea. However, the former exists as a surface plume while the latter forms a subsurface dome. Furthermore, while the $\mathrm{N}: \mathrm{P}$ ratio in the upwelling water, about 14.5 , is typical of that in marine waters, the river water is nitrate-rich. Water with excess nitrate, the concentration of [nitrate + nitrite] in excess of that which may be utilized by marine phytoplankton at the observed concentration of phosphate, has been found to cover about a third to a half of the East China Sea Shelf (Wong et al., 1998). Another source of allochthonous combined nitrogen is the product of nitrogen fixation. The abundant 
presence of Trichodesmium spp. in the Kuroshio suggests that nitrogen-fixation may occur in this oligotrophic water. The $\delta^{15} \mathrm{~N}$ of nitrate suggests that nitrogen-fixation may be responsible for $20 \%$ of the nitrate that is transported to the East China Sea Shelf by upwelling (Liu et al., 1996).

The work in this issue focused on the temporal and spatial variations in the nutrient dynamics and biological production in the East China Sea. Gong et al. (2000) observed that there were large temporal and spatial variations in biomass and primary production in the East China Sea and these variations were closely related to the chemical hydrographic conditions. The availability of light and nutrients were two main factors that led to these variations. Chen (2000) reported that pico-plankton were the dominant contributor to the biomass and primary production in the Kuroshio Water. In the upwelling region and the shelf water, while the contribution from the pico-plankton was still significant, the contribution from nano- and microplankton became dominant. Chang et al. (2000) found that the abundance of the nitrogen-fixing Trichodesmium varied spatially and temporally. The highest abundance was found in the Kuroshio and the lowest abundance was found in the coastal water. However, a high abundance could also be found in the nutrient poor Taiwan Strait Warm Water on the Shelf. Seasonally, the highest abundance was found in the summer and the lowest in the winter. Nitrogen fixation by Trichodesmium may support up to $25 \%$ of the new production in the Kuroshio. Shiah et al. (2000) found that bacterial biomass, production and the turn-over rate of bacterial biomass in the coastal and upwelling waters were at least two-fold of those in the Kuroshio. The bacterial production in the East China Sea Shelf was equivalent to about $25 \%$ of primary production. Thus, the bacterial carbon demand in the shelf area may consume organic carbon at a rate similar to that of the production of photosynthetically fixed carbon.

\section{Particle transport and sedimentary processes}

Away from the coastal zone, the East China Sea Shelf is covered with coarse grained calcareous sediments. Beyond the shelf break, a belt of organic-rich fine-grained sediment is found along the upper northwestern slope of the Okinawa Trough at depths of about 500-1000 m (Lin et al., 1992a,b). High apparent sedimentation rates based on the distribution of ${ }^{210} \mathrm{~Pb}$ and high inventories of excess ${ }^{210} \mathrm{~Pb}$ were also found in this belt of sediments (Chung and Chang, 1996). A similar belt of organic-rich fine-grained sediment was also found at the upper slope of the Mid-Atlantic Bight as a result of the "insulating" effect of the slope (Csanady and Shaw, 1983; Walsh et al., 1988). A similar mechanism may be operating at the slope of the East China Sea Shelf. This focusing effect on the accumulation of fine-grained sediments also suggests that authochthonous and any terrigenous fine-grained POC that can escape deposition in the coastal zone may undergo cross shelf transport and reach the Okinawa Trough. The cyclonic eddy at the shelf edge northeast of Taiwan may serve as a major conduit for the transport of particles from the southern East China Sea Shelf to the Okinawa Trough (Hsu et al., 1998). Terrigenous particles as well as biogenic particles formed in 
the shelf or in the upwelling zone are entrained into the eddy. They then settle to greater depths and are then transported to the Okinawa Trough, possibly especially through the submarine canyons.

In this issue, based on echogram characteristics, Hong and Chen (2000) presented a detailed description of the sedimentary regimes in the area north-east of Taiwan where the cyclonic eddy is found. Hung et al. (2000) and Chung and Hung (2000) studied sediment transport in the East China Sea. In general, both the concentrations of total suspended matter (TSM) and POC decrease from the inner shelf to the slope area. However, a local POC maximum was observed at the shelf break due to an enhanced primary production by upwelling. Mid-depth $(600 \pm 200 \mathrm{~m})$ maxima of TSM and DOC were repeatedly observed in the slope area, indicating a lateral transport of re-suspended sediment-particles offshore (Hung et al., 2000). The sediment trap data (Chung and Hung, 2000) indicate that the re-suspended sedimentparticles are transported mainly out of the shelf and slope areas through the MienHua Canyon. High sand and silt fluxes in the Mien-Hua Canyon were associated with strong tidal currents and episodic events. Lin et al. (2000) studied the diagenesis of organic carbon in the sediments of the East China Sea. Organic carbon deposition controls the formation of pyrite in the East China Sea Shelf sediments. The consumption of organic carbon by its oxidation through sulfate reduction in the sediments is equivalent to about $20 \%$ of the primary production.

\section{Conclusions}

In terms of the interactions between shelf-seas and the pelagic ocean, in general, the results from KEEP are consistent with the major findings of the Shelf Edge Exchange Processes experiment (SEEP) (Biscaye et al., 1994). However, the cyclonic cold eddy at the shelf edge northeast of Taiwan represents a different, and perhaps more effective, mechanism for the exchange of material between a shelf-sea and the waters further offshore. A definitive and comprehensive carbon budget for the East China Sea Shelf cannot yet be constructed. However, while the sum of the requirements for organic carbon for supporting the observed microbial biomass and activities in the water column and the sulfate reduction rates in the sediments exceeds primary production, there is strong evidence suggesting that a non-negligible fraction of the photosynthetically fixed carbon may have survived its oxidation on the Shelf and reach the Okinawa Trough. The mid-depth maxima in POC and TSM and the large fluxes of sinking particles found at the shelf edge northeast of Taiwan are consistent with an export of organic particles from the Shelf to the Okinawa Trough and these particles may be the source material for the belt of organic-rich sediments along the upper northwestern slope of the Trough. Furthermore, as reported in other shelves like the North Sea (Kempe and Pegler, 1991), the East China Sea Shelf is a net sink of atmospheric carbon dioxide.

The results from KEEP also suggest that some additions to and/or revisions in the present perception of the East China Sea Shelf as a biogeochemical system may be needed. (1) By far, the largest source of nutrients to the Shelf is through upwelling at 
the shelf break. The riverine input is significantly smaller by comparison. (2) The primary production in the East China Sea Shelf is significantly higher, at places 70\% higher, than previously reported estimates. (3) The volume transport to the East China Sea Shelf through the Taiwan Strait Warm Water may be significantly larger, $>1 \mathrm{~Sv}$, than previously envisioned. While that may not have much impact on the mass balance of nutrients since the Water is nutrient-impoverished, it may affect the water balance, the salt balance and the balance of other substances that are not depleted in the surface waters. (4) The cyclonic eddy at the shelf edge northeast of Taiwan is an important conduit for the exchange of material between the Shelf and its adjoining Kuroshio. While the upwelling of the Kuroshio Subsurface Water at the center of the eddy provides nutrients to the shelf, significant fractions of these upwelled nutrients also find their way back offshore into the Kuroshio Surface Water to sustain the primary production in the Kuroshio off the Shelf. Furthermore, this eddy may also facilitate the export of particles from the southern East China Sea Shelf to the Okinawa Trough. (5) Nitrogen fixation may also be an important source of new nitrogen for the oligotrophic Kuroshio Surface Water and the Taiwan Strait Warm Water in the East China Sea Shelf.

\section{Acknowledgements}

This work was supported in part by the National Science Council (Taiwan) through a grant to Shiah, and, by the National Science Foundation through grant numbers OCE-9301298 and INT-9515521 to Wong and INT-9417480 to Li. Wong was supported by the National Center for Ocean Research (NCOR) of Taiwan as a visiting scientist when this manuscript was prepared. We thank S. Lin, K.-K. Liu and C.-L. Wei for comments. This is NCOR Contribution No. 11.

\section{References}

Biscaye, P.E., Flagg, C.N., Falkowski, P.G., 1994. The shelf edge exchange processes experiment, SEEP-II: an introduction to hypothesis, results and conclusions. Continental Shelf Research 41, 231-252.

Chang, J., Chiang, K.-P., Gong, G.-C., 2000. Seasonal variation and cross-shelf distribution of the nitrogen-fixing cyanobacterium, Trichodesmium, in southern East China Sea. Continental Shelf Research 20, 479-492.

Chen, C., Beardsley, R.C., Limeburner, R., 1992. The structure of the Kuroshio southwest of Kyushu: velocity, transports and potential vorticity fields. Deep-Sea Research 39, 245-268.

Chen, C.-T.A., 1996. The Kuroshio intermediate water is the major source of nutrients on the East China Sea continental shelf. Oceanologica Acta 19, 523-527.

Chen, C.-T.A., 1998. The Kuroshio intermediate water is the major source of nutrients on the East China Sea continental shelf. Oceanologica Acta 21, 713-716.

Chen, C.-T.A., Ruo, R., Pai, S.-C., Liu, C.-T., Wong, G.T.F., 1995. Exchange of water masses between the East China Sea and the Kuroshio off northeastern Taiwan. Continental Shelf Research 15, 19-39.

Chen, C.-T.A., Ruo, R., Pai, S.-C., Liu, C.-T., Wong, G.T.F., 1999. Artifacts introduced into the calculation of the mixing ratios of seawater end-members using T-S properties: a reply. Continental Shelf Research 19, 295-298. 
Chen, Y.-L.L., 1995a. Temporal and spatial changes of chlorophyll $a$ in the KEEP study waters off northern Taiwan. Terrestrial, Atmospheric and Oceanic Sciences 6, 607-620.

Chen, Y.-L.L., 1995b. Phytoplankton composition and productivity in response to the upwelling off northeastern Taiwan. Proceedings of the National Science Council, ROC Part B: Life Sciences 18, 127-133.

Chen, Y.-L.L., 2000. Comparisons of primary productivity and phytoplankton size structure in the marginal regions of southern East China Sea. Continental Shelf Research 20, 437-458.

Chen, Y.L., Hu, H., Shiah, F.K., Gong, G.C., Liu, K.K., Kanda, J., 1998. New production and $f$-ratio on the continental shelf of the East China Sea: comparisons between nitrate inputs from the subsurface Kuroshio Current and the Changjiang River. Estuarine, Coastal and Shelf Science 48, 59-75.

Chern, C.-S., Wang, J., 1990a. On the mixing of waters at a northern offshore area of Taiwan. Terrestrial, Atmospheric and Oceanic Sciences 1, 297-306.

Chern, C.-S., Wang, J., 1990b. On the Kuroshio branching current north of Taiwan. Acta Oceanographica Taiwanica 25, 55-64.

Chern, C.-S., Wang, J., 1992a. On the seasonal variation of the Kuroshio intrusion onto the East Chin Sea. Acta Oceanographica Taiwanica 29, 1-17.

Chern, C.-S., Wang, J., 1992b. The influence of Taiwan Strait waters on the circulation of the Southern East China Sea. La Mer 30, 223-228.

Chern, C.-S., Wang, J., Wang, D.-P., 1990. The exchange of Kuroshio and East China Sea shelf water. Journal of Geophysical Research 93, 16017-16023.

Chu, T.Y., 1976. Study of the Kuroshio current between Taiwan and Ishigakijima. Acta Oceanographica Taiwanica 6, 1-24.

Chuang, W.S., Wu, C.K., 1992. Slope current fluctuations northeast of Taiwan, winter 1990. Journal of the Oceanographic Society of Japan 47, 185-193.

Chuang, W.S., Li, H.W., Tang, Y.T., Wu, C.K., 1993. Observations of the countercurrent on the inshore side of the Kuroshio northeast of Taiwan. Journal of Oceanography 49, 581-592.

Chung, Y., Chang, W.C., 1996. Pb-210 fluxes and sedimentation rates on the lower continental slope between Taiwan and the south Okinawa Trough. Continental Shelf Research 15, 149-164.

Chung, Y.-C., Hung, G.-W., 2000. Particulate fluxes and transports on the slope between the southern East China Sea and the South Okinawa Trough. Continental Shelf Research 20, 571-597.

Csanady, G.T., Shaw, P.T., 1983. The "insulating" effect of a steep continental slope. Journal of Geophysical Research 66, 7519-7524.

Fan, K.-L., 1980. On upwelling off northeastern shore of Taiwan. Acta Oceanographica Taiwanica 11, $105-117$.

Fan, K.-L., 1982. A study of water masses in Taiwan Strait. Acta Oceanographica Taiwanica 13, 140-153.

Fan, K.-L., Yu, C.-Y., 1981. A study of water masses in the seas of southernmost Taiwan. Acta Oceanographica Taiwanica 12, 94-111.

Gong, G.-C., Chen, Y.-L.L., Liu, K.-K., 1996. Chemical hydrography and chlorophyll distribution in the East China Sea in summer: implications in nutrient dynamics. Continental Shelf Research 16, $1561-1590$.

Gong, G.-C., Shiah, F.-K., Liu, K.-K., Chuang, W.-S., Chang, J., 1997. Effect of Kuroshio intrusion on the chlorophyll distribution in the southern East China Sea north of Taiwan during Spring, 1993. Continental Shelf Research 17, 79-94.

Gong, G.-C., Shiah, F.-K., Liu, K.-K., Wen, Y.-H., Liang, M.-H., 2000. Spatial and temporal variation of chlorophyll $a$, primary productivity and chemical hydrography in the southern East China Sea. Continental Shelf Research 20, 411-436.

Guo, Y.J., 1991. The Kuroshio. Part II. Primary production and phytoplankton. Oceanography and Marine Biology Annual Review 29, 155-189.

Harada, K., Tsunogai, S., 1986. ${ }^{226}$ Ra in the Japan Sea and the residence time of the Japan Sea water. Earth and Planetary Science Letters 77, 236-244.

Hong, E., Chen, I.S., 2000. Echo characters and sedimentary processes along a rifting continental margin, northeast of Taiwan. Continental Shelf Research 20, 599-617.

Hsu, M.-K., Liu, A.K., Liu, C., 2000. A study of internal waves in the China Seas and Yellow Sea using SAR. Continental Shelf Research 20, 389-410. 
Hsu, S.-C., Lin, F.-J., Jeng, W.-L., Tang, T.Y., 1998. The effect of a cyclonic eddy on the distribution of lithogenic particles in the southern East China Sea. Journal of Marine Research 56, 813-832.

Hsueh, Y., Wang, J., Chern, C.-S., 1992. The intrusion of the Kuroshio across the continental shelf northeast of Taiwan. Journal of Geophysical Research 97, 14 323-14330.

Hsueh, Y., Chern, C.-S., Wang, J., 1993. Blocking of the Kuroshio by the continental shelf northeast of Taiwan. Journal of Geophysical Research 98, 12351-12359.

Hung, J.-J., Lin, P.-L., Liu, K.-K., 2000. Dissolved and particulate organic carbon in the Southern East China Sea. Continental Shelf Research 20, 545-569.

Jan, S., Chern, C.-S., Wang, J., 1994. A numerical study on currents in the Taiwan Strait during summertime. La mer 32, 225-234.

Kempe, S., Pegler, K., 1991. Sinks and sources of $\mathrm{CO}_{2}$ in coastal seas: the North Sea. Tellus 43B, 224-235.

Li, Y.-H., 1994. Material exchange between the East China Sea and the Kuroshio Current. Terrestrial, Atmospheric and Oceanic Sciences 5, 625-631.

Lin, C.Y., Shyu, C.Z., Shih, W.H., 1992a. The Kuroshio fronts and cold eddies off northeastern Taiwan observed by NOAA-AVHRR imageries. Terrestrial, Atmospheric and Oceanic Sciences 3, 225-242.

Lin, S., Liu, K.K., Chen, M.P., Chen, P., Chang, F.Y., 1992b. Distribution of organic carbon in the KEEP area continental margin sediments. Terrestrial, Atmospheric and Oceanic Sciences 3, 365-377.

Lin, S., Huang, K.-M., Chen, S.-K., 2000. Organic carbon deposition and its control on iron sulfide formation of the Southern East China Sea continental shelf sediments. Continental Shelf Research 20, 619-635.

Liu, C.-T., 1983. As the Kuroshio turns: (I) characteristics of the current. Acta Oceanographica Taiwanica $14,88-95$.

Liu, C.-T., Pai, S.-C., 1987. As Kuroshio turns: (II) the oceanic front north of Taiwan. Acta Oceanographica Taiwanica 18, 49-61.

Liu, K.-K., 1998. Comments on "The Kuroshio Intermediate Water is the major source of nutrients on the East China Sea continental shelf" by Chen (1996). Oceanologica Acta 21, 709-712.

Liu, K.-K., 1999. Artifacts introduced into the calculation of the mixing ratios of seawater end-members using T-S properties. Continental Shelf Research 19, 281-293.

Liu, K.-K., Pai, S.-C., Liu, C.-T., 1989. Temperature-nutrient relationships in the Kuroshio and adjacent waters near Taiwan. Acta Oceanographica Taiwanica 21, 1-17.

Liu, K.-K., Su, M.-J., Hsueh, C.-R., Gong, G.-C., 1996. The nitrogen isotopic composition of nitrate in the Kuroshio Water northeast of Taiwan: evidence of nitrogen fixation as a source of isotopically light nitrate. Marine Chemistry 54, 273-292.

Liu, K.-K., Tang, T.Y., Gong, G.-C., Chen L.-Y., Shiah, F.-K., 2000. Cross-shelf and along-shelf nutrient fluxes derived from flow fields and chemical hydrography observed in the southern East China Sea off northern Taiwan. Continental Shelf Research 20, 493-523.

Liu, K.-K., Gong, G.-C., Shyu, C.-Z., Pai, S.-C., Wei, C.-L., Chao, S.-Y., 1992a. Response of Kuroshio upwelling to the onset of the northeast monsoon in the sea north of Taiwan: Observations and a numerical simulation. Journal of Geophysical Research 97, 12 511-12 526.

Liu, K.-K., Gong, G.-C., Lin, S., Yang, C.-Y., Wei, C.-L., Pai, S.-C., Wu, C.-K., 1992b. The year-round upwelling at the shelf break near the northern tip of Taiwan as evidenced by chemical hydrography. Terrestrial, Atmospheric and Oceanic Sciences 3, 243-276.

Nozaki, Y., 1989. Mean residence time of the shelf water in the East China and the Yellow Seas determined by ${ }^{228} \mathrm{Ra} /{ }^{22} \mathrm{Ra}$ measurements. Geophysical Research Letters 16, 1297-1300.

Nozaki, Y., Tsunota, H., Kasemsupaya, V., Yashima, M., Ikuta, N., 1991. Residence times of surface water and particle-reactive ${ }^{210} \mathrm{~Pb}$ and ${ }^{210} \mathrm{Po}$ in the East China and Yellow seas. Geochimica Cosmochimica Acta 55, 1265-1272.

Shaw, P.-T., 1989. The intrusion of water masses into the sea southwest of Taiwan. Journal of Geophysical Research 94, 18 213-18226.

Shiah, F.-K., Gong, G.-C., Liu, K.-K., 1995. A preliminary survey on primary productivity measured by the ${ }^{14} \mathrm{C}$ assimilation method in the KEEP area. Acta Oceanographica Taiwanica 34, 1-15.

Shiah, F.K., Gong, G.C., Liu, K.K., 1996. Light effects on phytoplankton photosynthesis performance in the southern East China Sea north of Taiwan. Botanical Bulletin of the Academia Sinica 37, 133-140. 
Shiah, F.-K., Liu, K.-K., Kao S.-J., Gong G.-C., 2000. The coupling of bacterial production and hydrography in the southern East China Sea: spatial patterns in spring and fall. Continental Shelf Research 20, 459-477.

Su, J.L., Guan, B.X., Jiang, J.Z., 1990. The Kuroshio. Part I. Physical features. Oceanography and Marine Biology Annual Review 28, 11-71.

Sverdrup, H.U., Johnson, M.W., Fleming, R.H., 1942. The Oceans Their Physics Chemistry and General Biology. Prentice-Hall, Englewood Cliffs, NJ, 1087pp.

Tang, T.Y., Yang, Y.C., 1993. Low frequency current variability on the shelf break northeast of Taiwan. Journal of Oceanography 49, 193-210.

Tang, T.Y., Hsueh, Y., Yang, Y.J., Ma, J.C., 1999. Continental slope flow northeast of Taiwan. Journal Physical Oceanography 29, 1353-1362.

Tang, T.Y., Tai, J.H., Yang, Y.J., 2000. The flow pattern north of Taiwan and the migration of the Kuroshio. Continental Shelf Research 20, 349-371.

Tseng, C., Lin, C., Chen, S., Shyu, C., 2000. Temporal and spatial variations of sea surface temperature in the East China Sea. Continental Shelf Research 20, 373-387.

Walsh, J.J., Biscaye, P.E., Csanady, G.T., 1988. The 1983-1984 Shelf Edge Exchange Processes (SEEP)-I experiment: hypotheses and highlights. Continental Shelf Research 8, 435-456.

Wang, J., Chern, C.-S., 1988. On the Kuroshio branch in the Taiwan Strait during wintertime. Progress in Oceanography 21, 469-491.

Wang, J., Chern, C.-S., 1992. On the distribution of bottom cold waters in Taiwan Strait during summertime. La mer 30, 213-221.

Wang, S.-L., Chen, C.-T.A., Hong, G.-H., Chung, C.-S., 2000. Carbon dioxide and related parameters in the East China Sea. Continental Shelf Research 20, 525-544.

Wang, Y., Editor-in-Chief, 1991. Marine Atlas of Bohai Sea, Yellow Sea, East China Sea - Chemistry, Editorial Board of Marine Atlas, China Ocean Press, Beijing, China, 257pp.

Wong, G.T.F., Pai, S.-C., Chen, C.-T.A., 1989. Chemical hydrography across the East China Sea-Kuroshio frontal region northeast of Taiwan. Acta Oceanographic Taiwanica 23, 1-18.

Wong, G.T.F., Pai, S.-C., Liu, K.-K., Liu, C.-T., Chen, C.-T.A., 1991. Variability of the chemical hydrography at the frontal region between the East China Sea and the Kuroshio north-east of Taiwan. Estuarine, Coastal and Shelf Science 33, 105-120.

Wong, G.T.F., Gong, G.-C., Liu, K.-K., Pai, S.-C., 1998. 'Excess Nitrate' in the East China Sea. Estuarine, Coastal and Shelf Science 46, 411-418.

Wyrtki, K., 1961. Physical oceanography of the Southeast Asian waters. NAGA Report Vol. 2, Scientific Results of Marine Investigations of the South China Sea and the Gulf of Thailand, Scripps Institution of Oceanography, La Jolla, California, 195pp.

Yin, F., 1973. Preliminary study of cold water mass near N.N.E. of Taiwan. Acta Oceanographica Taiwanica 3, 157-180.

Zhang, J., 1995. Geochemistry of trace metals from Chinese river/estuary systems: a overview. Estuarine, Coastal and Shelf Science 41, 631-658.

Zhang, J., Liu, M.G., 1994. Observations on nutrient elements and sulfate in atmospheric wet deposition over the northwest Pacific coastal oceans - Yellow Sea. Marine Chemistry 47, 173-189.

Zhang, J., Huang, W.-w., Liu, M.-g., 1994. Geochemistry of major Chinese river estuary systems. In: Zhou, D., Liang, Y.-B., Zeng, C.-K. (Eds.), Oceanology of China Seas, Vol. 1. Kluwer, Netherlands, pp. 179-188.

Zhang, J., Letolle, R., Martin, J.M., Jusserand, C., Mouchel, J.M., 1990. Stable oxygen isotope distribution in the Huanghe (Yellow River) and the Changjiang (Yangtze River) estuarine systems. Continental Shelf Research 10, 369-384. 